\title{
Evaluation of Tarbiat Modares University brand based on University Brand Ecosystem Model
}

\author{
Hossein Khanifar \\ Associate professor, Faculty of management, Iran, University of Tehran, Qom College \\ (hkhanifar@yahoo.com)
}

\section{Mohammad Rahim Esfidani}

Professor assistant, Faculty of management, Iran, University of Tehran (esfidani@ut.ac.ir)

\author{
Hossein Nazari \\ MA in Business management, Faculty of management, Iran, \\ University of Tehran, Qom College (hossein.na.65@gmail.com)
}

\section{Jalal Naderi}

MA in Business management, Faculty of management, Iran, University of Tehran, Qom College (Naderi_64@yahoo.com)

DOI: 10.6007/IJARBSS/v3-i7/91 URL: http://dx.doi.org/10.6007/IJARBSS/v3-i7/91

\begin{abstract}
Purpose - Analyzing organization brand is a way to services perception. Tarbiat Modares University is a university in Iran-Tehran. We have considered brand of this university in order to providing a basis for analyzing student satisfaction, creating value for its brand and providing an efficient model for managing it. For this purpose we use University Brand Ecosystem Model presented by Pinar et al (2011).

Design/methodology/approach - For collecting data a questionnaire was designed consisting of 63 questions which measure student satisfaction, academic activities, supporting activities, and the effect of external factors on brand of Tarbiyat Modares University. Factor analysis shows 5 questions are inappropriate therefore we removed them. The Statistical Population is all students of Tarbiyat Modares University and the sample is 95 persons based on the Cochran formula.

Findings - Findings show that academic activities (student-student, student-employee and student-faculty relationships) influence student satisfaction and Tarbiyat Modares university brand, but from supporting activities, just community service and student life entered the model. And also only two factors of external components "alumni and employers" entered the model
\end{abstract}


Practical implications - This survey can help Tarbiat Modares University to identify its weaknesses, develop strategies to overcome them and further improve the community's image of itself.

Originality/value - This paper presents the crucial dimensions of university activities for building successful brand.

Keywords: University Brand, student satisfaction, academic activities, supporting activities, external components

Article Type: Research paper

Keywords: University Brand, Student satisfaction, Academic activities, Supporting activities, External components.

\section{Introduction}

Brand is a valuable asset which influences both internal and external stakeholders of any organization (Go \& Govers, 2010).The real value of a brand is its ability to capture customer preferences and loyalty. Brand as a valuable intangible asset is a strong factor for organizations to create differentiations and also it is a decision tool for customers. Branding is an integral part of marketing strategies. Since branding efforts are not limited to goods, various service companies also use this strategy to create a strong brand. However universities have concluded that they should have brand strategy. Thus creating a brand is a strategic factor for a university through which it can makes a significant difference between its competitors ( Pinar, Trapp, Girard, \& Boyt, 2011).

Creating a strong brand requires some activities of the company (such as market research, market positioning, marketing mix) which expected to affect customers (their perceptions, their beliefs, attitudes, etc.) (Spyropoulou, Skarmeas, \& Katsikeas, 2011). Brand building is a key factor in marketing and it means more than making a name for a product (Fan , 2005).In the service companies, branding success depends on careful attention to the role of employees which provide services. With regarding to employees as internal stakeholders, they become more satisfied. This enhances the development of customer awareness and market trends (Papasolomou \& Vrontis, 2006). Service quality means meetingcustomers' expectations. Good services enhance the social importance of commercial companies. In addition, it improves comparative advantage and customers' satisfaction (Herstein \& Eyal, 2006). Today in the complex and competitive world, universities and colleges have turned to branding as a strategy to deal with the challenges.Challenges such as how make a difference between themselves (various universities) to be an option for selecting by students ( Pinar, Trapp, Girard, \& Boyt, 2011).As a result, many organizations often find themselves in the managing of their brand, among different people and different situations (Aaker, 1996).Although choosing a university is more complicated than a product (due to the quality, cost and performance courses), it can be operated the same way that the product branding is, soit should be noted that what is the brand's offers (Brewer \& Zhao, 2010).

Branding in Higher Education helps students and their parents to identify university services and also it is an encouraging factor for using those services.Assessments and perceptions of 
students and alumni are used for analyzing quality of university services.Branding in higher education is not only to create differentiation; but used to create a sense of belonging to the university soits members have such a sense of belonging to it that encourage them to introduce themselves with that brand (Curtis, Abratt, \& Minor, 2009).Pinar et al (2011)presented a model for university branding called "University brandecosystem". This model divided university activities into three parts includes academic activities, supporting activities and external factors. They state that students are the core value and the most important stakeholder of university ( Pinar, Trapp, Girard, \& Boyt, 2011).This model is presented as follows:

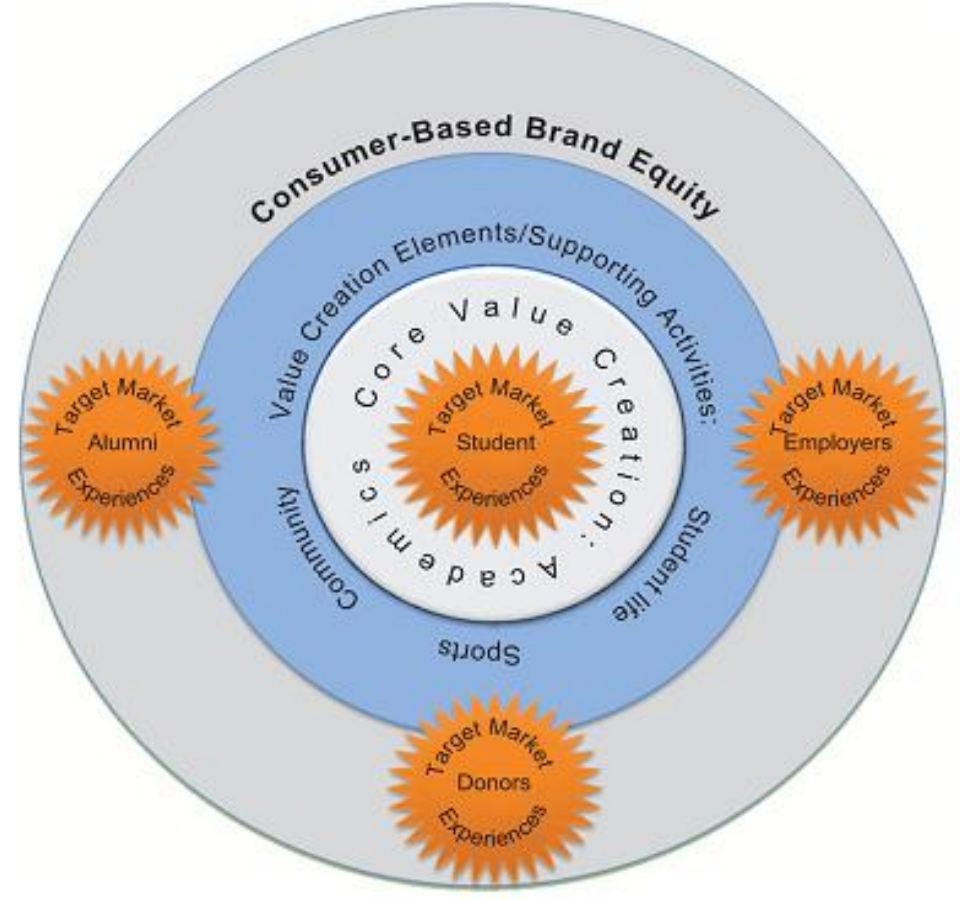

Figure 1: University Brand Ecosystem Model ( Pinar, Trapp, Girard, \& Boyt, 2011)

Students are referred to as the main customers of higher education, Sirvanci considers four roles for the student include: process product, internal customers for facilitate, active learning process and ultimately internal customers to meet and receive information periodically (Zavar, Behrangi, Asgarian, \& Naderi , 2007). Each of the three proposed activities can be divided into more components. Like other services, educational experience as a process is a set of dependent factors include student-students interactions, students-faculty interactions and student-employee interactions. Each of them has a potential impact on academic quality, student experiences and finally university brand.For example, academic activities can be a series of class discussions, assignments, tests, group projects, training, research projects that are offered by universities, internet communication with the professor about the course, etc.These entirefactors are considered as the central elements of brand value. Supporting activities such as application process, tuition, university facilities and residential services are given a central role in the core activities so the importance of student engagement with supporting services in creating brand value is clear. For examplethe student interactions in dormitory, university tuition and facilities may increase or decrease student satisfaction fromcentral activities ( Pinar, Trapp, Girard, \& Boyt, 2011). 
Goals: This study sought to evaluate the brand of Tarbiat Modares University based on university brand ecosystem model.In fact we are going to determine the factors affecting the brand of this university from the perspective of student satisfaction. Finally, we provide revised model for this university. So they can use it in their marketing and branding activities and also in creating student satisfaction.

\section{Literature review}

Student satisfaction: Stakeholders of higher education are students, staff, teachers, families, communities and industries.Butitsmain stakeholders are students.Sirvanci considers four roles for students include: product process, internal customers to facilitate, active learning process and ultimately internal customers to meet and receive information periodically. And also Parasuraman present a model for measuring quality of service.This model has five dimensions includeoutward manifestation and tangible factors, reliability, accountability, assure and guarantee empathy and compassion (Zavar, Behrangi, Asgarian, \& Naderi , 2007). Universities as a learning environment should provide the necessary positive changes in student attitudes to encourage and create stable learning. For this purpose assessment of student attitudes about services is essential. Using this information can strengthen the positive factors and correcting the negative factors and thereby provide students satisfaction.Students as one of the main pillars of university are the main body of different organizations in the future sotheir satisfaction of activities conducted at the university, can affect attitudes toward motivation for creating and maintaining quality education (Sohrabiyourtchi, Mousakhani, Shafia, \& Yazdani, 2010).

Academic activities (core value creation): In the university brand ecosystem model, academic activities (such as training and research)are proposed as the core of value creation process.Academic activities are as health factors (Herzberg theory) it means their existence does lead to satisfaction but their failure to deliver will cause dissatisfaction.Learning experience is the results of events such as interactions between student - faculty, student employee and students - students. Each of them can affect the quality of teaching, academic experience and ultimately affect the university brand ( Pinar, Trapp, Girard, \& Boyt, 2011).Riddell considered three approaches to educational reform. First: economic perspectives: there are close links between education and economy. At this point of view, education is evaluated in two ways include production functions and performance. Those who look from the perspective of production functions, emphasis on effective combination of training resources and other inputs for improving educational management.Second: education centered reform: This emphasizeon learning opportunities, educational planners and donors. In this view three standards are examined effectiveness of institution, institution improvement and relationships between students - professors. Third is political view: The diversity of this perspective is the amount of all universities that have their own policy (Riddell, 1999).

Yamamoto and Karaman (2011) list the main features of education systems as follow:

- Geographical affiliations

- Specific services to people with disabilities and poor

- Create long-term training

- Flexible training 
- The new attitude in classes and courses

- Combination and coordination of academic life with work life (Yamamoto Gonca \& Karaman, 2011).

Supporting activities:supporting activities such as the application process, tuition, accommodation and welfare facilities and services are given a central role in the service activities. For example, student life can be assessed by factors such as student relationships with dining staff, taste of food, or at a broader level, student life is a collection of experiences that each student take in his/her interaction with other sections. Also the student interactions in dormitory, university tuition and facilities may increase or decrease student satisfaction about central activity ( Pinar, Trapp, Girard, \& Boyt, 2011).Availability of services causes students to develop their interests and skills. For this purpose, a series of social programs and strategies should be run in universities like training, advise, leadership development, increase improvement opportunities and continuous support (Kiker, 2008). Other issue of supporting activity is sport. University athletic programs can create a platform in which integration and collaboration take place at the university. Today, modern universities offer a variety of services such as research, printing, job training, health and hospital facilities and sports programs. Set up a sports program at the university has been introduced as a means to fulfill the needs of students (Spivey, 2008).

\section{External factors:}

Alumni: Studying about alumni provides a tool for assessing the skills and knowledge needed in the workplace. If universities looking to satisfying their students and alumni, they must adjust their training programs with the work environment needs. A way for applying training programs successfully is creating Alumni Association which can give advice about programs and their applications (Guevara \& Stewart, 2011).Alumni can be one of the most valuable resources for universities; and their contributions whether financial, strategic or social can add credibility and longevity. Alumni activities include financial support, associations, social development and participation in the strategic positioning of university (Barnard \& Chris, 2008).

Donors: If an organization want to attract charitable resources provide by donors, must expand its communication with them. The best way to provide appropriate conditions for communication is doing research about them. Waters (2008) provides two major ways for absorbing donors. First, we should not only pay attention to those donors who have enormous contributions with organization and should design some principles totreat equally with all donors. It will increase donors' loyalty. The second way is to monitor and manage them. This steps outlined four elements include:

- Reciprocity: it means organization appreciates donors.

- Responsibilities: The organization use appropriately received gifts, according to its social responsibilities.

- Report: This element includes the main principles of the responsibility.

- Communication: it includes communicational and motivational activities.

These principles help organizations to increase and maintain financial support (Waters, 2008). The recipient should inform donors about the achievement from their aids by creating 
communication with them. Those donors, who are aware of the credit system of organization, are more loyal and even increase their help (Iwaarden, Wiele, Williams, \& Moxham, 2009).

Employer:In the twentieth century the interaction between universities and workplace was considered as an important factor for bran value. Reports in England showed there is a need for trained workforce, familiar person with the work environment and development employee skills such as communication, using technology and learning (Paisey \& Paisey, 2010). Research shows that employers provide many financial resources of staff training and education in universities. Type and level of employer contributions to employees (who are students) is very divers; but most types of aids are paying all or part of direct costs of the course (Cappelli, 2004).

Methodology: For collecting data a questionnaire was designed consisting of 63 questions which measure student satisfaction, academic activities, supporting activities, and the effect of external factors on brand of Tarbiyat Modares University. This questionnaire was created by researchers, so we did factor analysis on it and this analysis shows 5 questions are inappropriate therefore we removed them. Reliability of the questionnaire was 0.961 based on Cronbach's alpha. The Statistical Population is all students of Tarbiyat Modares University and the sample is 95 persons based on the Cochran formula.

\section{The hypothesis framework}

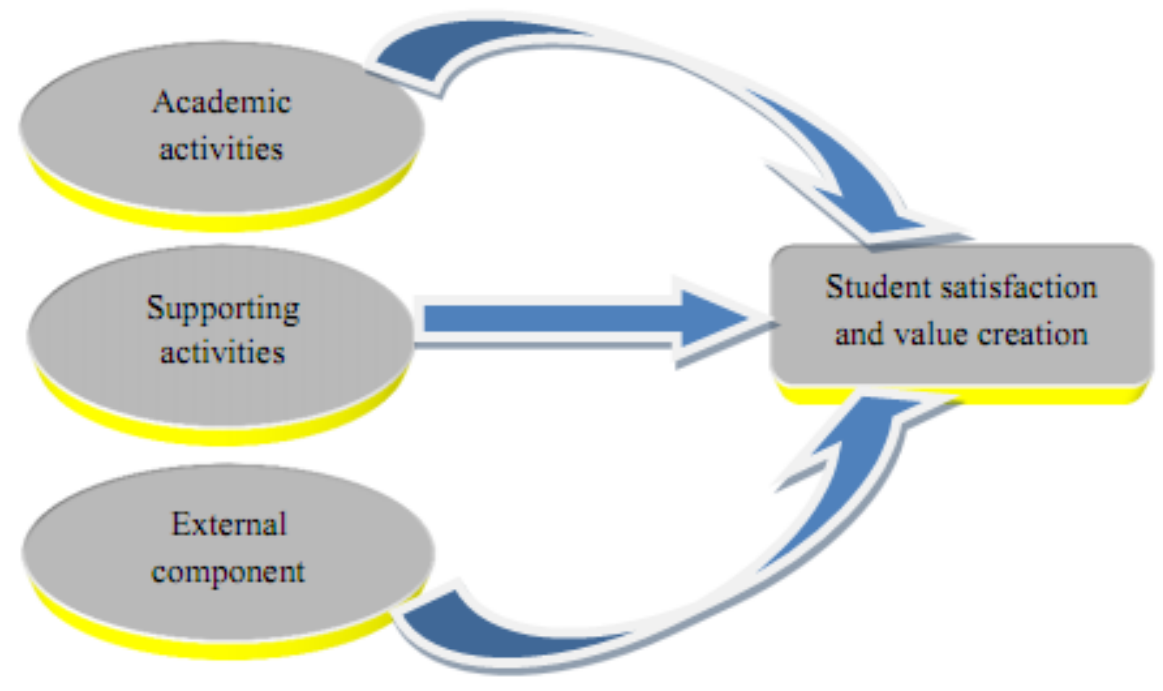

Findings:

Figure 2: Hypothesis Framework

\section{Demographic variables}

Study of demographic variables showed that 70 percent of respondents were male and 30 percent were female. And 80 percent of them were MA and 20 percent of them were PhD. At first we analyze the subject that whether significant difference exist between satisfaction of 
men and women or MA and Ph.D. students. Analysis showed there is no significant difference between them.

The first hypothesis: academic activities have a significant effect on student satisfaction and thereby on creating brand value.

To test the first hypothesis, three components include student-Student, Student-Faculty and student-employee was tested through stepwise regression analysis. The following results were obtained:

\begin{tabular}{|l|l|l|l|}
\hline \multicolumn{3}{|c|}{ Variables Entered/Removed } \\
\hline $\begin{array}{l}\text { Mode } \\
1\end{array}$ & $\begin{array}{c}\text { Variables } \\
\text { Entered }\end{array}$ & $\begin{array}{l}\text { Variables } \\
\text { Removed }\end{array}$ & Method \\
\hline 1 & $\begin{array}{l}\text { Student. } \\
\text { Faculty } \\
\text { Student. }\end{array}$ & $\cdot$ & $\begin{array}{l}\text { Stepwis } \\
\text { e }\end{array}$ \\
\hline 2 & $\begin{array}{l}\text { Student } \\
\text { Student. } \\
\text { Employee }\end{array}$ & $\begin{array}{l}\text { Stepwis } \\
\text { e }\end{array}$ \\
\hline 3 & $\cdot$ & $\begin{array}{l}\text { Stepwis } \\
\text { e }\end{array}$ \\
\hline Dependent Variable: satisfaction & \\
\hline
\end{tabular}

Table 1: Variables Entered/Removed for the first hypothesis

In stepwise regression analysis, components are coming into the model in order of their importance (Habibpoor \& Safdari , 2009). Here is clear that all three factors have great impact on satisfaction. The most effective component is student-faculty relationship and then studentstudent relationship and finally the relationships between employees and students.

\begin{tabular}{|c|c|c|c|}
\hline Model & $\mathrm{B}$ & $\mathrm{t}$ & $\mathrm{sig}$ \\
\hline Constant & 0.531 & 2.322 & 0.022 \\
\hline $\begin{array}{c}\text { Student. } \\
\text { FacultyStudent. } \\
\text { Student }\end{array}$ & 0.350 & 3.757 & .000 \\
\hline $\begin{array}{c}\text { Student. } \\
\text { Employee }\end{array}$ & 0.283 & 3.698 & .000 \\
\hline
\end{tabular}


Table 2: Coefficient table of first hypothesis

This table made by the stepwise regression so the regression model for academic activities can be presented as follows:

$$
Y=\alpha+\beta 1 \times 1+\beta 2 \times 2+\ldots+\beta n \times n=Y=0.531+0.35 X_{1}+0.283 X_{2}+0.262 X_{3}
$$

In this model, $x 1$ represents the student - faculty, $x 2$ represents the student - student and $x 3$ represent the student -employee relationship.

The second hypothesis: supporting activities have a significant effect on student satisfaction and thereby on creating brand value.

To test the second hypothesis, we considered three factors include student life, university sports and social or community services and then analyze its impact on student satisfaction and thereby creating value for university brand. The following results were obtained:

\begin{tabular}{|c|c|c|c|}
\hline \multicolumn{4}{|c|}{ Variables Entered/Removed } \\
\hline $\begin{array}{l}\text { Mo } \\
\text { del }\end{array}$ & $\begin{array}{c}\text { Variables } \\
\text { Entered }\end{array}$ & $\begin{array}{l}\text { Variables } \\
\text { Removed }\end{array}$ & Method \\
\hline 1 & Social.En & . & $\begin{array}{c}\text { Stepwis } \\
\text { e }\end{array}$ \\
\hline 2 & Student. Life & . & $\begin{array}{c}\text { Stepwis } \\
\text { e }\end{array}$ \\
\hline De & ent Variable & ction & \\
\hline
\end{tabular}

Table 3: Variables Entered/Removed for the second hypothesis

It is clear from the above table, social environment is considered as the most important factor and the first variable entered to the model. Student life is the second variable that entered the model.

\begin{tabular}{|c|c|c|c|}
\hline Model & B & t & sig \\
\hline Constant & 1.415 & 6.323 & 0.000 \\
\hline Social.En & 0.450 & 5.563 & 0.000 \\
\hline Student life & 0.185 & 2.622 & 0.010 \\
\hline
\end{tabular}

Table 4: Coefficient table of second hypothesis

This table made by the stepwise regression so the regression model for supporting activities can be presented as follows:

$$
Y=\alpha+\beta 1 \times 1+\beta 2 \times 2+\ldots+\beta n \times n
$$


In this model, $\mathrm{x} 1$ represents the social or community services and $\mathrm{x} 2$ represent the student life component.

The third hypothesis: external components have a significant effect on student satisfaction and thereby on creating brand value.

In this hypothesis we examine the effects three components include alumni, donors and employers on student satisfaction and value creation for university brand.

\begin{tabular}{|l|c|c|c|}
\hline \multicolumn{3}{|c|}{ Variables Entered/Removed } \\
\hline Mo & Variables & Variables & Metho \\
del & Entered & Removed & d \\
\hline 1 & alumni & & $\begin{array}{c}\text { Stepwis } \\
\text { e }\end{array}$ \\
\hline 2 & employer & & Stepwis \\
& & & e \\
\hline \multicolumn{2}{|l|}{ Dependent Variable: satisfaction } \\
\hline
\end{tabular}

Table 5: Variables Entered/Removed for the third hypothesis

This table shows that between external factors, alumni is the most important factor and then employers which entered the model as the second variable in influencing student satisfaction and thereby creating value for university brand.

\begin{tabular}{|c|c|c|c|}
\hline Model & $\mathrm{B}$ & $\mathrm{t}$ & $\mathrm{sig}$ \\
\hline Constants & 1.028 & 4.197 & .000 \\
\hline Alumni & 0.407 & 4.324 & .000 \\
\hline Employers & 0.355 & 4.183 & .000 \\
\hline
\end{tabular}

Table 6: Coefficient table of third hypothesis

We can extract regression model related to external factors from this table, which is as follows: In this model, $x 1$ represents the alumni and $x 2$ represent the employers' component.

$$
\mathrm{Y}=\alpha+\beta 1 \times 1+\beta 2 \times 2+\ldots+\beta \mathrm{n} \times \mathrm{Y}=\mathrm{Y}=1.028+0.407 \mathrm{X}_{1}+0.355 \mathrm{X}_{2}
$$

Based on the results, the proposed model for Tarbiat Modares University is presented as follow: 


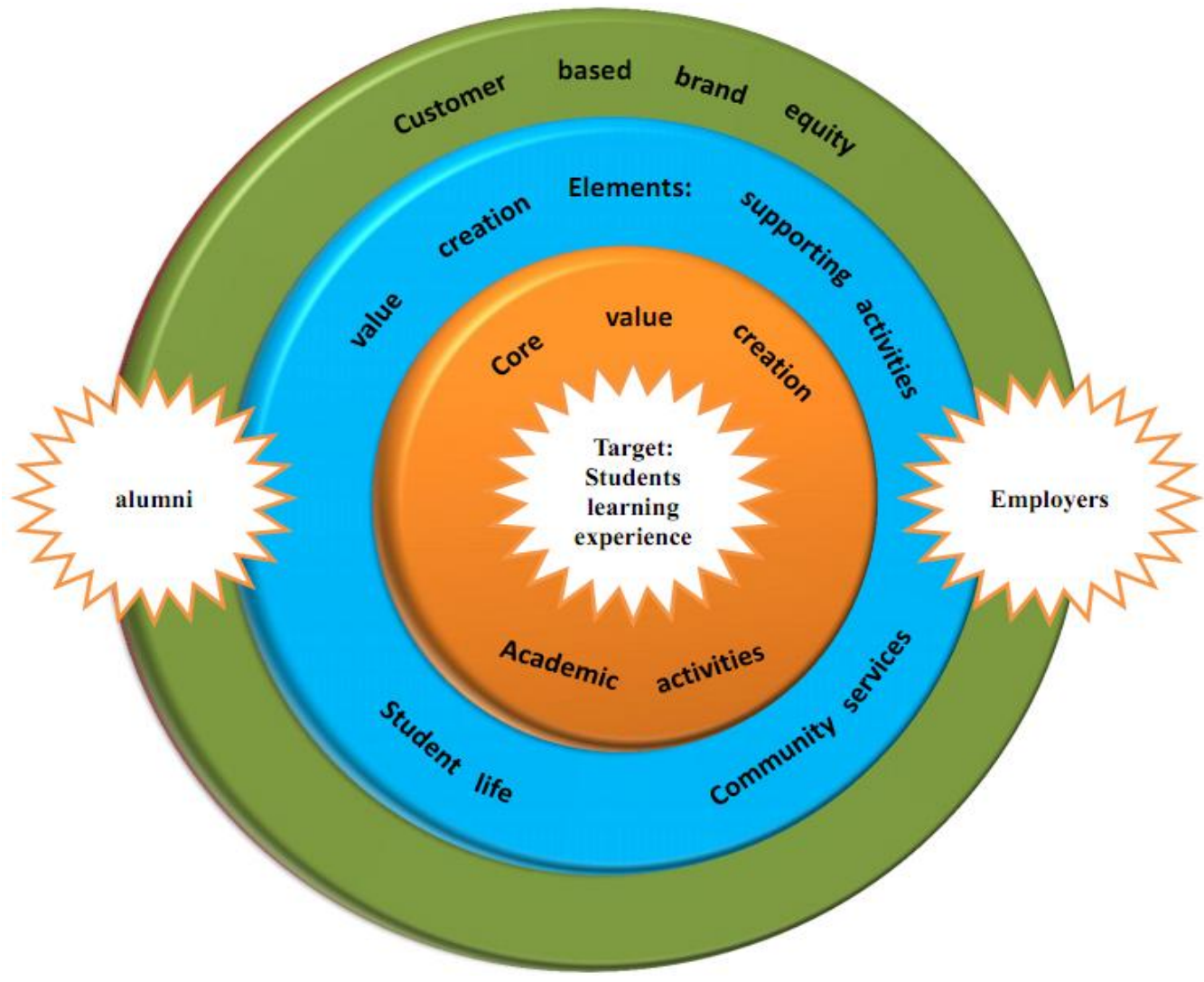

Figure 3: Tarbiat Modares Brand Ecosystem Model

Revised model of University Brand Ecosystem for this university

\section{Discussions}

One of the most important factors for success in university is students' experiences. As Pinar et al (2011) have expressed, academic experience considered as the driving force in creating value for university brand. Therefore, Tarbiat Modares University should pay more attention to their students to act properly in order to satisfy them. There are three levels of activities students involved with during their course include academic activities, supporting activities and external factors. These activities will lead to students' academic experience.According to the proposed model, these three levels for Tarbiat ModaresUniversity are described as follows:

Academic activities: according to results, academic activities influence student satisfaction in Tarbiat Modares University includes interactions between the student-faculty, student-student and student-employee. Among these three factors, student-faculty relationship has a coefficient of 0.35 and has the greatest impact on student satisfaction. Student relationships with faculty include teaching and research activities like courses, projects proposed by university and academic knowledge. According to Quinsee and Bullimore two factors include operations and resource planning, can be considered as educational activities related to faculty (Quinsee \& Bullimore, 2011). Another factor to create a positive academic experience is "primary sources" (Lindquist \& Long , 2011); they have expressed digital primary sources have a 
great effect on creating a positive educational experience and its benefits can be stated as follows: more availability, more flexibility and ability to stronger search. Oandasan and Reeves list key elements for interprofessional education: Using educational theory, create a learning environment without fear and creating relevant learning experiences (Oandasan \& Reeves, 2005). One of the important goals of Tarbiat Modares University is achieving, maintaining and developing a research position and increasing share of scientific production in national, regional and international level. Since the scientific productions are made by students, this universitymust meet the educational and research needs of students for achieving its goals. For this purpose the following suggestions are offered for:

- Planning to provide relevant materials in the classroom

- Using educational theory in teaching and planning such as schools and economic theory, linguistic code, hidden program, education and cultural reproduction

- Providing training courses for students in any field they interested in

- Planning for use of resources properly and coordinating them with student needs

- Expansion of digital facilities for students such as digital libraries

- Create a healthy and competitive environment without fear and stress

- Using view of Riddle on educational reform especially training based in which three aspects are examined include institutional effectiveness, improving institution and student-teacher relationships.

The second factor of academic activities that are entered the model is student-student interaction. This emphasizes the interactions between students in the classroom and school environment and also dormitory. As is clear the factor coefficient is 0.283 in influencing student satisfaction. Seeman and O'Hara'sresearch focused on customer (students) relationship management in higher education or universities. They said advantages of these relationships are focusing on students, improving processes and increasing management's commitment to programs and services of university (Seeman \& O'Hara , 2006).As Pinar et al (2011) said good relations between students influence on their learning that ultimately lead to improved learning experience in university and also their satisfaction. This process will lead to value creation for university and its brand. Some suggestions for improving these relationships in Tarbiat Modares University are given below:

- Create student organizations on campus such that students be able to engage in group work

- Strengthening the Scientific Association at the University to increase student academic activities

- Emphasis on group works in class and creates a good working interaction between students

- Encourage students to participate in academic and sports competitions to increase empathy among university students

The third factor of academic activities that is entered the model is student-employee interaction and its coefficient is 0.262 . Gault et al (2010) provide different skills in these areas such as the desire to learn new skills, consistency in performance, motivation, the behavior based on ethical values, commitment to quality work and professional behavior (Gault, Leach, $\&$ Duey , 2010). These factors are the characteristics of a good employee in university. Studentstaff relationships are the most important factors in affecting student satisfaction and creating 
learning experiences for them. Without motivated employees creating positive experiences for students seems to be impossible. These relationships include staff and professors relationships with students. The following suggestions for improving these relationships in Tarbiat Modares University are presented:

- Implementing the tests measure social skills when hiring

- Implementing Training courses to enhance communication and social skills of employees

- Develop problem-solving ability of employees

- Improve working conditions for employees to increased their satisfaction, commitment and motivation.

Supporting activities: supporting activities alsoinfluence on university brand. Supporting activities such as the application process, tuition, accommodation and welfare facilities have important role in supporting academic activities. For example student life can be seen by factors such as student relationships with dining staff, with food taste, or at a broader level, student life is a collection of experiences each student made in interactions with other sectors. Also student interactions in dormitory, university fees and facilities may increase or decrease student satisfaction. Between supporting activities, in this study, two factors include social environment (or community) and student life are affecting student satisfaction and create value for Tarbiat Modares university brand. As the model is specified, social environment is the most important factor for Tarbiat Modares University among supporting activities. Its coefficient is 0.407 and it is entered into the model as the first factor. These factors include the environment in which students interact with others such as classroom environment, student associations, communicating with friends and etc. To improve the social environment of Tarbiat Modares University, we offer the following suggestions:

- Create facilities such as parks, health and friendly social environment between students

- Allow students to create different clubs and organizations (academic, cultural, sports, etc.) for social work

- Providing various conferences and appreciate active students in different fields such as cultural or sport

Another factor of supporting activities which entered into the model is student life. This factor more emphasis on accommodation and student life facilities especially in dormitory and college environment.Since many students are not native in Tarbiat Modares University, paying attention to dormitories is important for student satisfaction as one of the factors of value creation for the university brand. The following suggestions are offered to improve these factors:

- Select a location for dormitory to be close to the university to prevent wasting time

- Providing items which are essential for living in a dormitory

- Pay attention to sports

- Providing loans to students, especially those who do not have the ability to pay tuition

- Improve food quality in university dining

External factors: other part of university brand ecosystems model is external factors. In this study by doing regression test, two factors include alumni and employers entered the model for Tarbiat Modares University. Alumni are the interpreter of learning experience. They are the 
most influential individuals in transmitting positive or negative perceptions to people who just want to enter the university or studying at university. Also about employers who are active in the community, we can say if there are some institutions or companies which emphasis on certain university for hiring people, it will impact on the brand of that university.

Guevara and Stewart (2011) in their study among alumni and students conducted to identify student's satisfaction factors concluded that career relevance is an important factor for student satisfaction. But they said that it must be evaluated by alumni. Similarly, Daud et al (2011) expressed managers should take the training programs according to the factors are expected by alumni to be responsive to market and industry needs (Daud, Abidin, Sapuan, \& Rajadurai , 2011). Therefore Tarbiat Modares University should maintain its contact with alumni to impose their views on planning and also make a relationship between them and the students continually. According to the model and the coefficient of 0.407 for the alumni, it is clear that this is the most important among external factors. One way to establish this relationship is creating University Alumni Association. In this case, students can easily communicate with them and contact with them as a consultant. Another effective way in this area is inviting successful alumni for lectures and conferences in universities. Holding such meetings lead to faster and better transfer of alumni's perceptions to students and can increase motivation and commitment of students. Another factor of external factors entering the model is employer that affects student satisfaction with a coefficient of 0.355.Cappelli (2004) ask: why employers are willing to pay for some universities alumni? He said it is because of some benefits has created for employers such as higher quality, lack of turnover and stay for a longer time. Given these results we can sayemployers pay attention to alumni who have these features. So Tarbiat Modares University can make such alumni by setting relevant material into the chart and also creating good culture. Therefore employers be able to trust them and can be as a source of income for university.

\section{References}

Aaker, D. (1996). Building strong brand. Boston, Massachusetts: Harvard Business Press.

Barnard, Z., \& Chris, R. (2008). Investigating online community portals for enhanced alumni networking. Journal of The Electronic Library, 26(4), 433-434.

Brewer, A., \& Zhao, J. (2010). The impact of a pathway college on reputation and brand awareness for its affiliated university in Sydney. International Journal of Educational Management, 24(1).

Cappelli, P. (2004). Why do employers pay for college? Journal of Econometrics, 121, 214-215.

Curtis, T., Abratt, R., \& Minor, W. (2009). corporate brand management in higher education: the case of ERAU. Journal of Product \& Brand Management, 18(6), 406. 
Daud, S., Abidin, N., Sapuan, N. M., \& Rajadurai , J. (2011). enhancing university business curriculum using an importance-performance approach. International Journal of Educational Management, 25(6).

Fan , Y. (2005). Ethical branding and corporate reputation. Corporate Communications: An International Journal, 10(4), 342.

Gault, J., Leach, E., \& Duey, M. (2010). Effects of business internships on job marketability: the employers' perspective. Education+Training, 25(1).

Go, f. M., \& Govers, R. (2010). International place branding yearbook 2010. England: Palgrave Macmillan.

Guevara, C., \& Stewart, S. (2011). Do student evaluations match alumni expectations? Journal of Managerial Finance, 37(7), 611-619.

Habibpoor, K., \& Safdari , R. (2009). Comprehensive guide for spss used in research studies. Tehran: Loye Publication.

Herstein Ram, E. G. (2006). the role of private branding in improving service quality. Managing Service Quality, 16(3).

Herstein, R., \& Eyal, G. (2006). the role of private branding in improving service quality. Managing Service Quality, 16(3), 306-307.

Iwaarden, J. v., Wiele, T. v., Williams, R., \& Moxham, C. (2009). Charities: how important is performance to donors? International Journal of Quality \& Reliability Management, 26(1), 5-6.

Kiker , J. (2008). Enhance Student Advising and Academic and Life Supports. Techniques, 83(3), 44-45.

Lindquist, T., \& Long , H. (2011). How can educational technology facilitate student engagement with online primary sources? Library Hi Tech, 29(2).

Oandasan, I., \& Reeves, S. (2005). Key elements for interprofessional education. Part 1: The learner, the educator and the learning context. Journal of Interprofessional Care, 1.

Paisey, C., \& Paisey, N. (2010). developing skills via work placements in accounting: Student and employer views. Journal of Accounting Forum, 34, 90.

Papasolomou, I., \& Vrontis , D. (2006). Building corporate branding through internal marketing: the case of the UK retail bank industry. Journal of Product \& Brand Management, 15(1), 39. 
Pinar, M., Trapp, P., Girard, T., \& Boyt, T. (2011). Utilizing the brand ecosystem framework in designing brand strategies for higher education. International Journal of Education Management, 25(7), 724-734.

Quinsee, S., \& Bullimore, A. (2011). creating the strategic learning environment at City University London. Campus-Wide Information Systems, 28(4).

Riddell, A. (1999). The need for a multidisciplinary framework for analyzing educational reform in developing countries. International Journal of Educational Development, 19, 209-214.

Seeman, E. D., \& O'Hara , M. (2006). Customer relationship management in higher education Using information systems to improve the student-school relationship. Campus-Wide Information Systems, 23(1).

Sohrabiyourtchi, B., Mousakhani, M., Shafia, S., \& Yazdani, H. (2010). Identifying factors in the formation of student satisfaction. Journal of Public Management Perspective(4).

Spivey, L. (2008). Division I Athletics Directors and University Presidents: A Comparison of SportRelated Values. a Dissertation Presented to the Faculty of the Department of Educational Leadership, 6-18. East Carolina University.

Spyropoulou, S., Skarmeas, D., \& Katsikeas, C. S. (2011). an examination of branding advantage in export ventures. European Journal of Marketing, 45(6), 915.

Waters , R. (2008). Applying relationship management theory to the fundraising process for individual donors. Journal of Communication Management, 12(1), 73-74.

Yamamoto Gonca, T., \& Karaman, F. (2011). Education 2.0. On the Horizon, 19(2), 109-110.

Zavar, T., Behrangi, M., Asgarian, M., \& Naderi , E. (2007). Quality assessment of educational services of Payamnor University in East and West azarbayejan. Journal of Research and Planning in Higher Education(46), 72-74. 